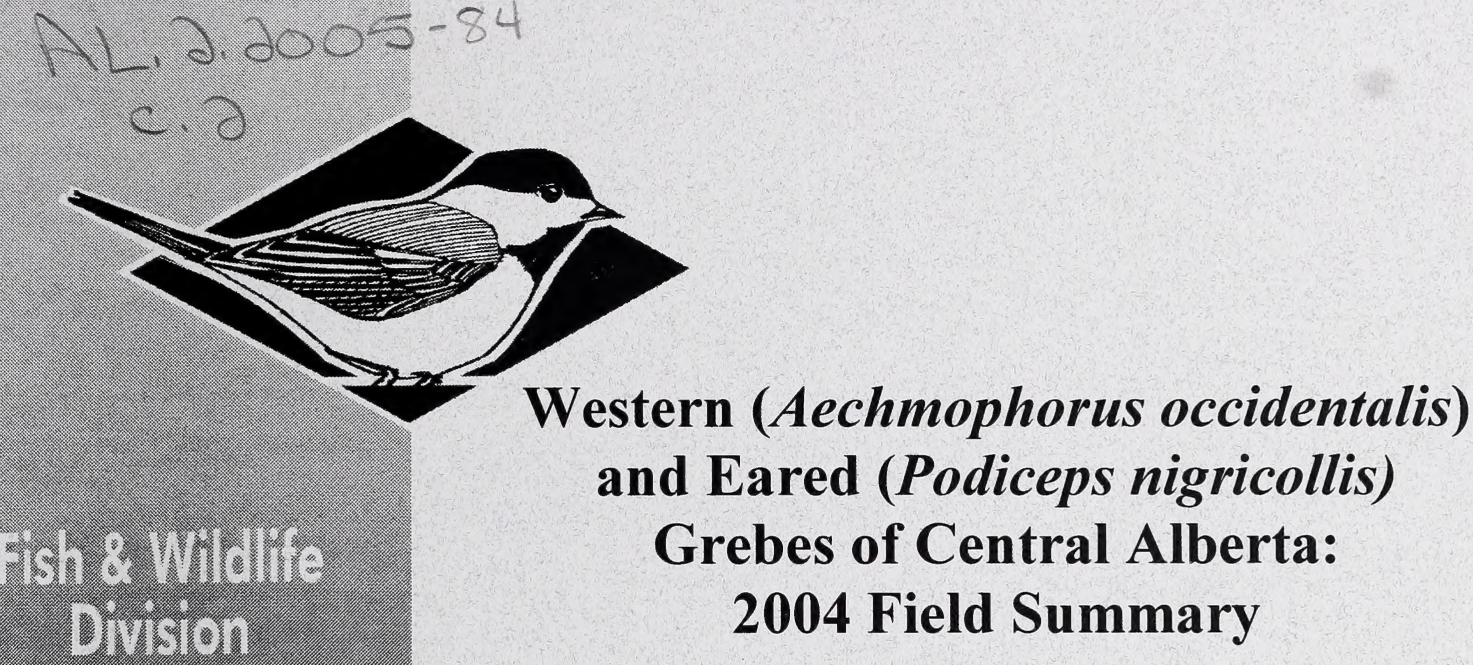

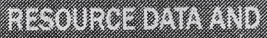

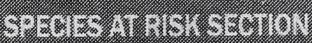

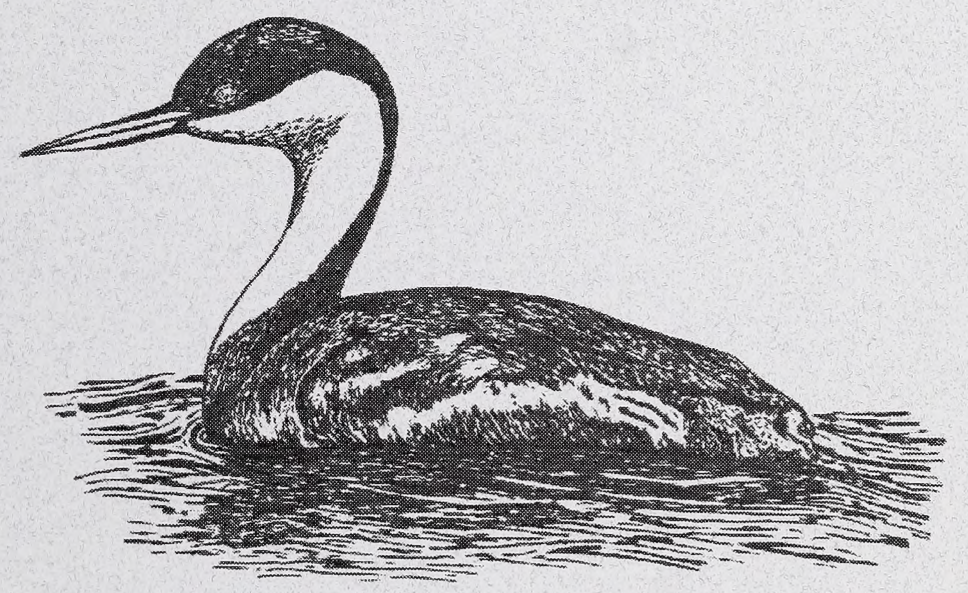

Alberta Species at Risk Report No. 94 
Digitized by the Internet Archive in 2016

https://archive.org/details/westernaechmopho00berg_0 


\title{
Western (Aechmophorus occidentalis) and Eared (Podiceps nigricollis) Grebes of Central Alberta: 2004 Field Summary
}

\author{
Gavin Berg \\ Lisa Wilkinson \\ Hugh Wollis \\ And \\ Dave Prescott
}

Alberta Species at Risk Report No. 94
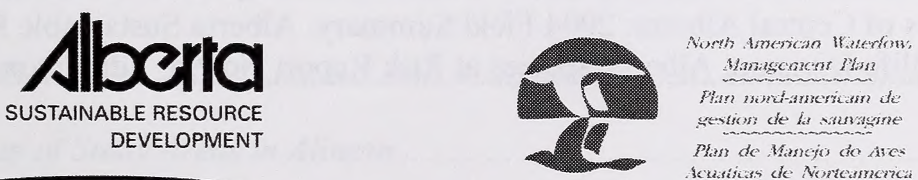
Publication No.: I/198

ISBN: 0-7785-3646-7 (Printed Edition)

ISBN: 0-7785-3647-5 (On-line Edition)

ISSN: 1496-7219 (Printed Edition)

ISSN: 1496-7146 (On-line Edition)

Illustration: Stephen Hanus

For copies of this report, contact:

Information Centre - Publications

Alberta Sustainable Resource Development

Main Floor, Great West Life Building

9920108 Street

Edmonton, Alberta, Canada T5K 2M4

Telephone (780) 422-2079

\section{OR}

Visit our website at:

http://www3.gov.ab.ca/srd/fw/riskspecies/

This publication may be cited as:

Berg, G., L. Wilkinson, H. Wollis, and D. Prescott. 2004. Western (Aechmophorus occidentalis) and Eared (Podiceps nigricollis) Grebes of Central Alberta: 2004 Field Summary. Alberta Sustainable Resource Development, Fish and Wildlife Division, Alberta Species at Risk Report No. 94. Edmonton, AB. 


\section{TABLE OF CONTENTS}

ACKNOWLEDGEMENTS

EXECUTIVE SUMMARY

1.0 INTRODUCTION

\subsection{STUDY AREA}

\subsection{METHODS}

3.1 Stony Plain Area. 8

3.2 Parkland Area 8

\subsection{RESULTS}

4.1 Stony Plain Area......

4.1.1 Western Grebes

4.1.2 Eared Grebes

4.2 Parkland Area

\subsection{DISCUSSION}

5.1 Western Grebes in the Stony Plain Area

5.2 Eared Grebes in the Stony Plain Area.

5.3 Western Grebe Populations in the Parkland Area.

5.4 Management Concerns and Human Impacts on Grebe Colonies

\subsection{LITERATURE CITED}

8.0 APPENDICES

Appendix 1. Map of Study Areas in Alberta.

Appendix 2. Western and eared grebe observations on lakes surveyed in 2004

Appendix 2 Western and eared grebe observations on lakes surveyed in 2004 (continued) 


\section{LIST OF FIGURES}

Figure 1. Total number of western grebe nests counted on colonies within the Stony Plain area, 2001-2004.

Figure 2. Estimated total number of eared grebes counted on lakes within the Stony Plain area, 2001-2004.

\section{LIST OF TABLES}

Table 1: Summary of Stony Plain western grebe data, 2004.

Table 2. Summary of eared grebe data, 2004

Table 3. Summary of western grebe observations in the Parkland Region, 2004. 


\section{ACKNOWLEDGEMENTS}

We thank Matt Besko of Alberta Sustainable Resource Development, Rick and Chantal Pattenden of Mainstream Aquatics Ltd, and Andrew Forrest, for their assistance during nest count surveys. Also, thank you to Jim Allen, Michelle Wells, Ken Froggatt, Leslie Beattie, Laura Froggatt, Ian Prescott, Eric Prescott, Jim Potter, and Kevin Wingert for their work with preliminary surveys of lakes in the Parkland area for grebe populations. Alberta Sustainable Resource Development provided funding and in-kind support. Additional funding was provided by the North America Waterfowl Management Plan, which was administered by the Alberta Conservation Association. 


\section{EXECUTIVE SUMMARY}

This project is in its fourth year and is designed to monitor population trends and reproductive success of western grebes and eared grebes within the Stony Plain, Alberta area. Surveys are projected to span a five-year period, and the results are being used for conservation and management efforts. Western grebes are the priority species because they are provincially listed as "sensitive". This project also provides information to support lake habitat conservation and public education. In 2004, surveying effort was focused on the primary western and eared grebe populations identified in the previous years of this project. Ground nest surveys were conducted after the nesting period, the results of which were used to derive a total breeding adult population estimate. In addition, surveys were initiated in the Parkland region in 2004, to identify waterbodies that supported potential western grebe breeding colonies.

We estimated the population of western grebes in the Stony Plain study area to be approximately 1270 adults, much lower than in 2003 (2554 adults), and lower than all previous years of study. Generally, nesting colony locations were similar to previous surveys. Western grebes inhabiting Wabamun Lake and Lac Ste. Anne continue to be the dominant populations in the study area, representing $54.1 \%$ and $26.3 \%$ of the regional population, respectively. Since 2003, the Wabamun Lake colony decreased in size by nearly $53 \%$ (likely due to high rates of corvid nest depredation), and the Lac Ste. Anne colony decreased by $72 \%$. These colonies were formerly considered nationally significant due to their size, but are now considered only regionally significant. The Isle Lake population is the only colony that grew in size, doubling from 2003. Western grebes appear to return each year to historical breeding sites on large lakes, and are vulnerable to human disturbance, making site protection essential. In particular, critical reed habitat for nesting colonies is being cleared as a result of human development.

In 2004, eared grebe colony searches were conducted on fifteen lakes. Eared grebes were observed on nine lakes, for a conservative overall population estimate of 8865 adults. Only seven of these lakes had breeding colonies, and three of these lakes supported the aforementioned western grebe colonies. The number of eared grebes observed in 2004 was higher than all previous years of study, including a dramatic increase from 2003 (up from 1880+). This increase can be attributed to a colony found on Majeau Lake (3594+ adults), in a part of the lake that was not surveyed previously. For the fourth consecutive year, George Lake supported the largest eared grebe population in the study area; numbers increased significantly from 2003 but are slightly lower than 2002 surveys. Eared grebe population sizes and colony locations appear to be highly variable, suggesting that they rely on a network of waterbodies to sustain their regional population. Eared grebes appear to prefer shallow and undeveloped lakes and generally avoid waterbodies with extensive boating.

This is the first year for surveys in the Parkland Region of Alberta. Initial results found that of the eleven lakes surveyed, nine supported populations of western grebes, with the largest populations being located on Buffalo and Gull lakes. Although no evidence of breeding activity was recorded, surveys in future years will focus on trying to identify colonies and confirm breeding. Expanding western grebe colony surveys throughout the province will provide valuable information for status evaluation and conservation. 


\subsection{INTRODUCTION}

Western grebes (Aechmophorus occidentalis) and eared grebes (Podiceps nigricollis) are part of the family Podicipedidae, an ancient species of diving specialists that rarely fly except to migrate. These grebe species are colonial nesting waterbirds that build precarious floating nests of aquatic vegetation either secured to emergent vegetation or free-floating. Both species have wide distributions across western and central North America, with some colonies having thousands of nests.

As with many top predators in ecosystems highly impacted by humans, western and eared grebes are sensitive to these impacts and could become threatened over the long-term. Currently in Alberta, western grebes are listed as 'sensitive', while eared grebes are listed as 'secure' (Alberta Sustainable Resource Development 2000). This project was developed because of the relatively sparse data available to quantify these rankings. Surveying protocols have been developed and refined, population trend, distribution and measures of reproductive success within the study area are being monitored, and specific threats to western and eared grebe populations have been identified.

The information presented in this report represents the findings from the fourth year of surveying western and eared grebes within the Stony Plain study area in Alberta (Appendix 1), with comparisons to data from previous years of the study. Baseline data for this area for 2001 to 2003 are presented in Hanus et al. (2002a, 2002b, 2003). A synthesis of provincial data for western and eared grebes is provided in Hanus (2002). This report also includes data collected from the first year of surveying for western grebes in the Parkland region.

In 2004 our objectives were to:

1) Monitor the primary colonies of western and eared grebes in the Stony Plain study area (Appendix 1), with emphasis on western grebes due to their 'sensitive' status in Alberta;

2) Opportunistically inventory other lakes in the study area to locate new colonies;

3) Initiate western grebe surveys in the Parkland region; and

4) Assist with colonial waterbird surveys in Lac La Biche and Cold Lake areas.

\subsection{STUDY AREA}

A detailed description of the Stony Plain study area is provided in Hanus et al. (2002b). Briefly, this area is located in central Alberta (Appendix 1), and includes the counties of Barrhead, Lac Ste. Anne, Parkland, and Westlock. The legal land description for the study area includes townships 48 to 66 and ranges 23 to 28 west of the fourth meridian, and townships 48 to 66 and ranges one to nine west of the fifth meridian (i.e. between $53^{\circ}$ and $55^{\circ}$ north latitude, and $113^{\circ}$ and $115^{\circ}$ west longitude). The north/south and east/west maximum distances are approximately $143 \mathrm{~km}$ and $135 \mathrm{~km}$, respectively, and the total area is $11592.6 \mathrm{~km}^{2}$. Specific details of lakes with active and/or historic grebe breeding colonies are in Hanus et al. (2002b).

The Parkland study area is located just south and east of the Stony Plain study area. Briefly, this area includes the counties of Wetaskiwin, Ponoka, Red Deer, Camrose, Vegreville, Provost and Lloydminster. The legal land description for this area includes townships 34 to 58 and ranges 1 to 26 west of the fourth meridian, and townships 34 to 51 and ranges 1 to 5 west of the fifth meridian. A few additional lakes were surveyed outside of the Parkland region and were included in this data set for simplicity. 
The study areas are located within the parkland and boreal forest natural regions (Alberta Environmental Protection 1994), in a landscape where much of the original vegetation has been cleared for agricultural, urban, and industrial development. The proximity of the study area to several urban centres, such as the cities of Edmonton and Red Deer, make many of these lakes attractive for recreation and cottage development. Lakes are generally meso- to hyper- eutrophic.

\subsection{METHODS}

\section{$\underline{3.1 \text { Stony Plain Area }}$}

Field surveys occurred between June 16, 2004 and July 16, 2004. The focus in 2004 was to monitor the primary colonies identified by Hanus et al. (2002a,b), rather than conducting a broad inventory throughout the study area. Nevertheless, lakes with smaller populations and new sites were also surveyed whenever the opportunity arose.

In order to survey populations of western and eared grebes and to locate their nesting colonies, we used the meandering shoreline boat technique as described in Hanus et al. (2002b). Lakes surveyed in this manner included Brock Lake, Erickson Lake, George Lake, Lac Ste. Anne, Lessard Lake, Majeau Lake and Sandy Lake (Appendix 1). Several lakes or portions of lakes that were not suited to boating were surveyed using the shoreline telescope survey (Hanus et al. 2002b), and included Arthur Lake, Goose Lake, Schuman Lake, Oldman Lake and Prefontaine Lake (Appendix 1). Casual observations were also noted from Wakamao and Big Lakes.

For western grebes, total nest counts were conducted once the majority of nests were abandoned to ascertain the complete size of the colonies (Lac Ste. Anne - July 14, Wabamun Lake - July 15, and Lake Isle - July 15, August 4). All nests were counted and classified as intact, partially floating, or sunken, to derive an index of time since nest abandonment. Eared grebe nest counts, based from a canoe, were conducted on George Lake, Brock Lake and Majeau Lake. Total nest counts for eared grebes were conducted on George Lake (June 23), Majeau Lake (June 28) and Brock Lake (June 29). Clutch size was not determined, in order to reduce time spent near the colony and minimize disturbance.

Colony locations were recorded using Garmin ${ }^{\mathrm{TM}}$ model Etrex handheld global positioning (GPS) units set to NAD 83. For larger colonies, several GPS locations were recorded along their perimeter to provide an index of size.

\subsection{Parkland Area}

Surveys were conducted between June 2, 2004 and July 30, 2004. The focus in 2004 was to identify lakes with western grebe populations, and if possible, locate breeding colonies.

When conducting the surveys, researchers used the meandering shoreline boat technique as described in Hanus et al. (2002b). Lakes surveyed in this manner included Pigeon Lake, Gull Lake, Battle Lake, Pine Lake, Driedmeat Lake, Coal Lake, Glennifer Lake, Buffalo Lake, Orloff Lake, Buck Lake and Sylvan Lake. The number and location of western grebes were recorded for each lake. 


\subsection{RESULTS}

\subsection{Stony Plain Area}

We surveyed a total of 15 lakes between June 16 and July 16 (an additional survey was conducted August $4^{\text {th }}$ ) in 2004. A summary table of results, survey dates, and methods used for each lake surveyed is in Appendix 2. A summary of 2004 colony data is in Table 1 for western grebes, and Table 2 for eared grebes, and a comparison of colony sizes from 2001 to 2004 is in Figure 1 for western grebes, and Figure 2 for eared grebes.

\subsubsection{Western Grebes}

We estimated a total of 1270 adult western grebes, based on a count of 585 nests in three colonies. The largest adult western grebe populations and breeding colonies were observed on Wabamun Lake and Lac Ste. Anne, which represented $54.1 \%$ and $26.3 \%$ of the regional population, respectively.

A total of 114 nests were counted on Isle Lake in 2004, for an estimated colony size of 228 adults (Table 1). The Isle Lake colonies were located on two adjacent islands. The timing of counts of the west island colony on July $15^{\text {th }}$ proved to be a good time for grebes as nesting had mostly been completed (Appendix 3 ). However, the disturbance to the other colonial species, including Franklin's gulls and Forester's terns, was considered too great on the east island colony to do the survey at the same time. This survey was completed on August $4^{\text {th }}$ after most of the nesting by the terns and gulls was complete, but unfortunately, it was too late for a reliable count of grebe nests. Only 15 nests were identified, but there were likely others that were indistinguishable because they were in an advanced state of deterioration.

A total of 154 nests were counted on Lac Ste. Anne in 2004 at the traditional breeding site, for an estimated colony size of 308 adults (Table 1). The colony was in two discrete sections and at two different stages of breeding, as the southeast section appeared to have completed nesting earlier. Timing for the total nest count on July $14^{\text {th }}$ was slightly early since $24 \%$ of nests were still considered active. This value was similar to the extrapolated proportion of active nests from 2002 and 2003. Over $67 \%$ of nests were considered in good condition (i.e. intact or partly submerged; Appendix 3). An additional area at the west end of the middle basin of Lac St. Anne was surveyed, where western grebes were suspected to nest, but no nesting activity was observed.

A total of 317 nests were counted in 2004 at Wabamun Lake, for an estimated colony size of 634 adults (Table 1). By the time of the total nest count on July $15^{\text {th }}$ no nests were active and $86 \%$ of nests were in poor condition (i.e. submerged) suggesting earlier abandonment (Appendix 3). Crows were observed in and around the western grebe nesting area during the site visit, and evidence of egg depredation was apparent.

The western grebes observed on Sandy Lake in 2002 but not in 2003, were back in 2004, but there continued to be no evidence of breeding (Table 1). 


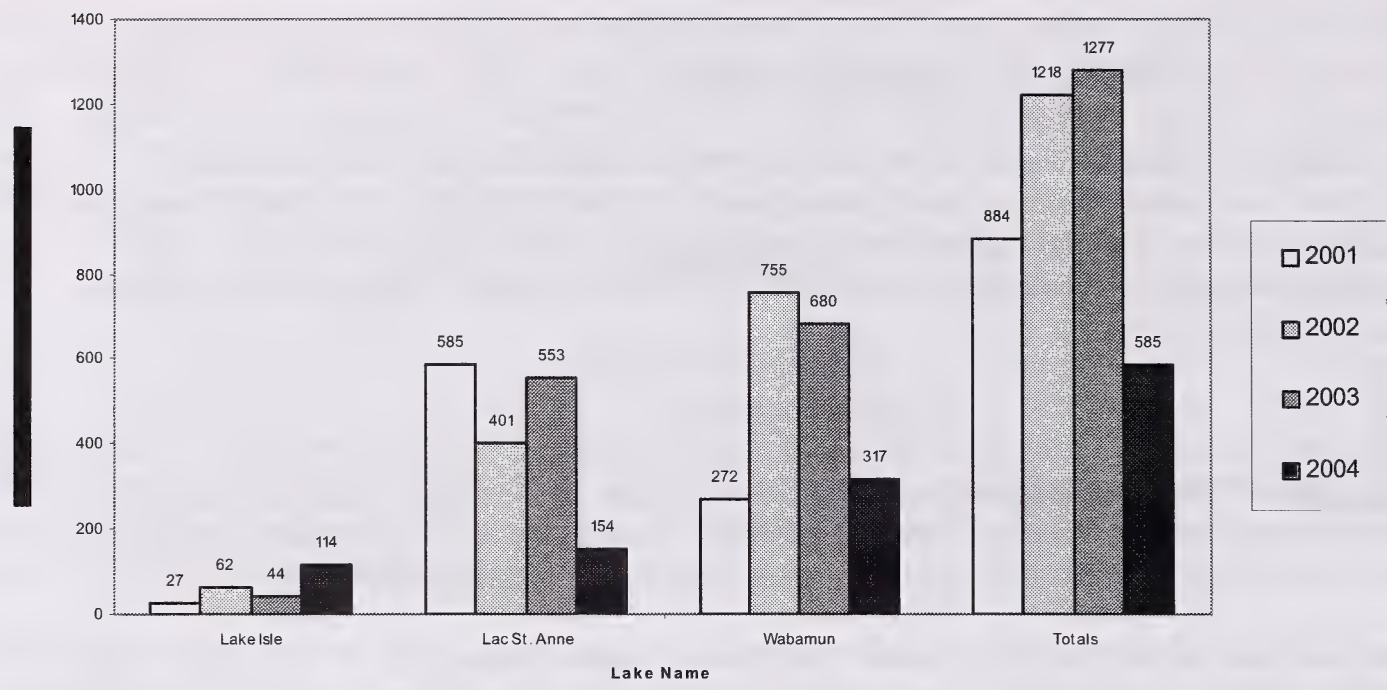

Figure 1. Total number of western grebe nests counted on colonies within the Stony Plain area, 2001-2004.

Table 1: Summary of Stony Plain western grebe data, 2004.

\begin{tabular}{|l|c|c|c|}
\hline Lake Name & $\begin{array}{c}\text { Survey } \\
\text { Date }\end{array}$ & \# of Adults & $\begin{array}{c}\text { \# of nests } \\
\text { observed }\end{array}$ \\
\hline Isle Lake & 15-Jul-04 & 228 & 114 \\
\hline Lac St. Anne (middle basin) & 25-Jun-04 & $50+$ & 0 \\
\hline Lac St. Anne (west basin) & 21-Jun-04 & 41 & 0 \\
\hline Lac St. Anne (east basin) & $14-J u l-04$ & 308 & 154 \\
\hline Sandy Lake & 05-Jul-04 & 9 & 0 \\
\hline Wabamun Lake & 15-Jul-04 & 634 & 317 \\
\hline Totals & & $\mathbf{1 2 7 0}$ & $\mathbf{5 8 5}$ \\
\hline
\end{tabular}

\subsubsection{Eared Grebes}

We conducted searches for eared grebes on 15 lakes, including the three lakes on which western grebes were found. We observed eared grebes on nine lakes, with breeding observed on seven of the lakes (Table 2). In addition, casual observations from Big and Wakamao Lakes indicated presence of eared grebes, but due to logistical constraints, further data were not gathered and these lakes are not included in this report. For the fourth consecutive year, the largest eared grebe colony was on George Lake with an estimated population of 4588 adults. Majeau Lake had the second largest population with an estimated 3594 adults. The colony was located in an area of Majeau Lake that had not been surveyed previously, although we suspected a colony was present in previous years. These two lakes combine for $92 \%$ of the regional population of eared grebes. All colonies identified in 2004 were found in open water areas, with only one exception at Isle Lake where nests were found in reed beds. 
Ring-billed gull nest predation was observed at the George and Majeau Lake colonies during nest count surveys. If we approached the nests too closely, grebes left their nests and gulls quickly approached the nests to consume eggs (we observed only one instance where a grebe returned to its nest and chased the gull away). Evidence of eggshell fragments in nests suggested ongoing predation. Steps have been taken to minimize disturbance during surveys (refer to Management Implications and Future Direction).

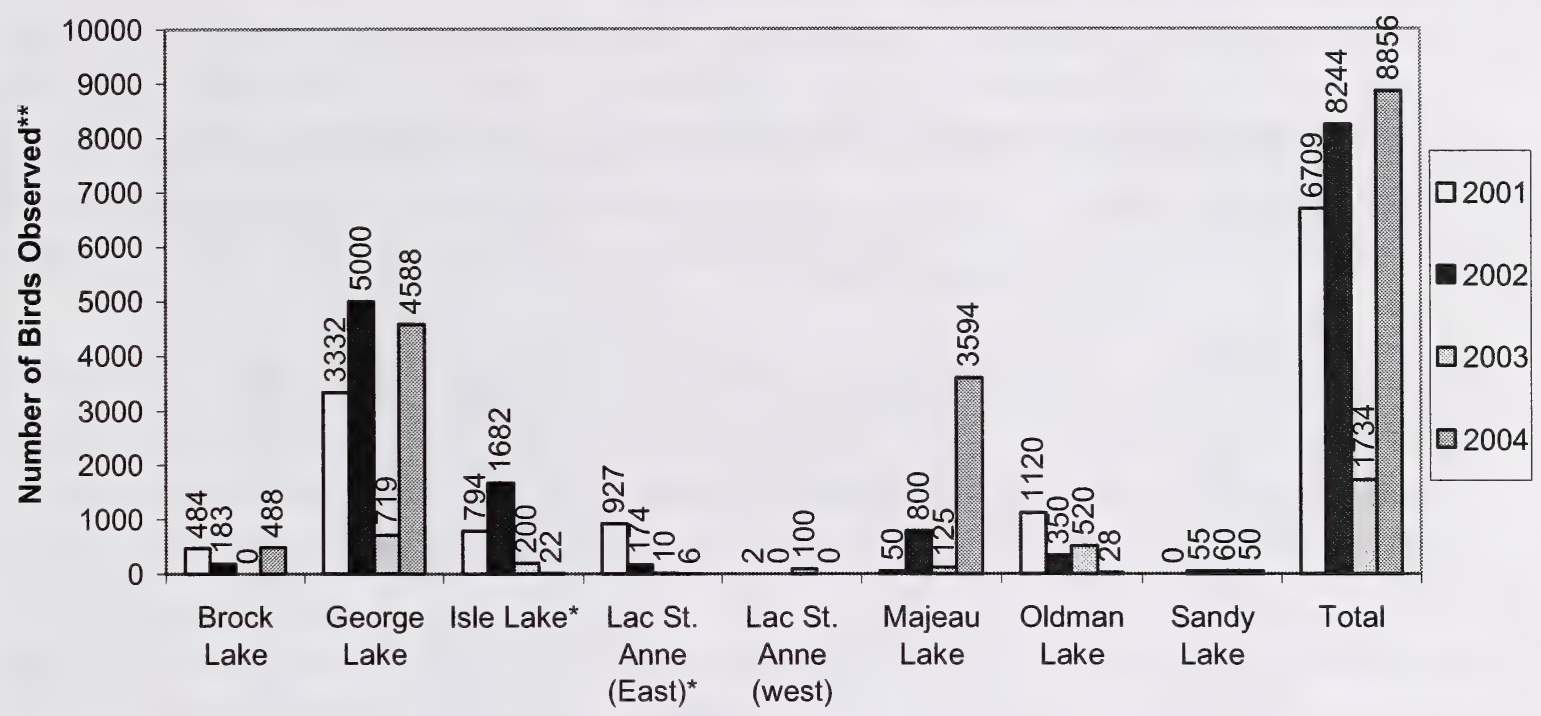

\title{
Lake Name
}

\begin{abstract}
*indicates only partial lake surveys
**population sizes estimated by doubling number of nests counted
\end{abstract}

Figure 2. Estimated total number of eared grebes counted on lakes within the Stony Plain area, 2001-2004.

Table 2. Summary of eared grebe data, 2004.

\begin{tabular}{|l|c|c|c|}
\hline Lake Name & $\begin{array}{c}\text { Survey } \\
\text { Date }\end{array}$ & \# of Adults & $\begin{array}{c}\text { \# of nests } \\
\text { observed }\end{array}$ \\
\hline Arthur Lake & 22-Jun-04 & 2 & 0 \\
\hline Brock Lake & 29-Jun-04 & 488 & 244 \\
\hline Chip Lake & 16-Jul-04 & $80+$ & 40 \\
\hline George Lake & 23-Jun-04 & 4588 & 2294 \\
\hline Isle Lake & 25-Jun-04 & 22 & 11 \\
\hline Majeau Lake & 28-Jun-04 & 3594 & 1797 \\
\hline Oldman Lake & 23-Jun-04 & 28 & 4 \\
\hline Sandy Lake & 5-Jul-04 & $50+$ & 0 \\
\hline Lac St. Anne (east basin) & 14-Jul-04 & 6 & 3 \\
\hline Totals & & $8858+$ & 4393 \\
\hline
\end{tabular}




\subsection{Parkland Area}

A total of 711 western grebes were observed on nine of the 11 lakes surveyed (Table 3), but no colonies were found. The highest numbers were on Buffalo and Gull Lakes. Buffalo Lake had extensive emergent vegetation and is likely the major breeding lake in the area. Gull Lake, however, had limited emergent vegetation, and thus has fewer potential nesting locations.

Table 3. Summary of western grebe observations in the Parkland Region, 2004.

\begin{tabular}{|c|c|c|c|}
\hline Lake & $\begin{array}{c}\text { Lake Location (Township, } \\
\text { Range, Meridian) }\end{array}$ & Date & \# WEGR \\
\hline Pigeon & T46, 47, R28, 01, 02, W4, 5 & 25 June 2004 & 20 \\
\hline Gull & T40-42, R28, 01, W4, 5 & 4 June 2004 & 320 \\
\hline Battle & T46, R02, W5 & 3 June 2004 & 0 \\
\hline Pine & T36, R24, 25, W5 & 30 July 2004 & 3 \\
\hline Driedmeat & T44, 45, R18-20, W5 & 18 June 2004 & 5 \\
\hline Buck & T46, R06, W5 & 12 June 2004 & 16 \\
\hline Orloff & T74, R23, 24, W4 & June / July & 0 \\
\hline Coal & T47, 48, R23, W4 & 18 June 2004 & 6 \\
\hline Glennifer & T35, R02, 03, W5 & 10 June 2004 & 10 \\
\hline Buffalo & T40, 40, R20, 21, 22, W4 & 2 June 2004 & 309 \\
\hline Sylvan & T38, 39 R01, 02, W5 & 30 June 2004 & 22 \\
\hline
\end{tabular}

\subsection{DISCUSSION}

\subsection{Western Grebes in the Stony Plain Area}

Western grebe colonies identified in 2001 were still present in 2004; however, the total population estimate was lower in 2004 than in any other year of the study (Figure 1). A certain amount of variation is expected due to imprecision associated with survey techniques, but this drop is noteworthy, even taking into account that two of the surveys may have under-represented the number of active nests. The western grebe population appears to have decreased by approximately $54 \%$ from 2003 (Hanus et al. 2003), 52\% from 2002 (Hanus et al. 2002b) and 33\% from 2001 (Hanus et al. 2002b). Poston et al. (1990) developed a ranking system for migratory birds inhabiting the Canadian Prairie Provinces, and classified western grebe colonies with over 500 nests or breeding pairs as nationally significant, and colonies with 100 to 500 nests or breeding pairs as regionally significant. Both Lac Ste. Anne and Wabamun Lake colonies have decreased from nationally significant to regionally significant. Surveys in northeastern Alberta also detected a decrease in western grebe populations from 2003 to 2004 (Found 2004).

With the exception of Isle Lake, the colonies have generally decreased throughout the four years of study. The location of the Isle Lake colony is split into two areas, and the distribution of nests has varied between years; hence, we expect a certain amount of variability in nest counts. It is possible that in the first year of study, when methods were being tested, colony size estimates were less accurate than in 
subsequent years. However, colonies at both Lac Ste Anne and Wabamun Lake have decreased significantly relative to 2002 ( $62 \%$ and 58\% respectively) and 2003 ( $72 \%$ and 53\% respectively; Figure 1 ). We suspect that nest predation by corvids is contributing to the decline of the Wabamun colony, and the high corvid population is likely a result of increasing human development along the lakeshore. One explanation for the change in numbers at Lac Ste. Anne is that we did not survey the reed beds to the north west of the colony in 2004 to confirm whether a satellite colony had been established. A satellite colony was found in 2001, but not in 2002 or 2003 . The area should be surveyed in 2005 for verification, however, it is unlikely that a satellite colony could account for the growing difference in population size between years. It is also possible that a stochastic environmental event at the wintering grounds could decrease the population size (e.g. Jehl et al. 2002). However, continued declines are likely related to site-specific conditions on breeding lakes, and Lac Ste Anne has a high level of human activity and development. Similarly, increasing human activity and degradation of shoreline habitat have been suggested as reasons for the apparent western grebe decline in northeastern Alberta, although changing water levels and natural population fluctuations are also possibilities (Found 2004).

Western grebes need to colonize large lakes, which provide adequate prey and areas of open water (refer to Hanus et al. 2002b); however, these lakes tend to have high levels of human activity. As an example, a proposed housing development adjacent to the western grebe colony on Lac Ste Anne has the potential to negatively impact nesting grebes by reducing and fragmenting nesting habitat, and increasing human presence and associated disturbances, including powerboats, dogs, and even corvids. Based on complete shoreline surveys for emergent vegetation habitat in 2002, the colony is located within the largest and most intact section of bulrush habitat remaining on the lake (Hanus et al. 2002a). Stringent mitigation measures are required to protect the colony, although the success of such measures is uncertain given the projected increase in human activity.

\subsection{Eared Grebes in the Stony Plain Area}

The regional eared grebe population in 2004 was 8858, almost 5 times greater than in 2003 (Figure 2), but similar to 2001 and 2002 (Hanus et al. 2002a,b, Hanus et al. 2003). If eared grebes from the newly discovered Majeau Lake colony are exempt, the revised estimate is approximately 5264 adults, which is still higher than 2003, but lower than 2001 and 2002 estimates (Figure 2). The most significant change in population occurred at George Lake between 2002 and 2004.

There are several possible explanations for the change in population estimates, such as imprecision associated with survey methods and reduced survey effort. Colonies built near the shoreline are often difficult to see and could easily be missed if entire lakes are not surveyed; only a partial lake survey occurred on George Lake in 2003 due to logistic constraints. Eared grebes may also have nested on alternate lakes not included in the survey (e.g. Majeau Lake prior to 2004). Eared grebes are able to use a variety of water bodies, with a preference for shallow wetlands $\leq 3 \mathrm{~m}$ deep (Boe 1992). Eared grebes may be faithful to breeding ponds or regions, but natal philopatry has not been documented (Cullen et al. 1999). Thus, we expect that eared grebes will not necessarily return to the same lake to breed every year, and may rely on a subset of lakes in the region.

Changes in water levels and other environmental factors, at both nesting and wintering sites, could also affect colony size. For example, in 1998, an E1 Nino event resulted in an increase in surface water temperatures at eared grebe wintering grounds, likely forcing prey to cooler water below the sustainable foraging depths of the grebes. This resulted in the starvation of hundreds of thousands of eared grebes and a huge drop in population numbers. In the following two years, the population rebounded to normal levels (Jehl et al. 2002). 
Several important breeding populations of eared grebes are present in the study area. Poston et al. (1990) defined nationally significant colonies as those over 800 nests, regionally significant colonies as having 300 to 800 nests, and locally significant colonies as having fewer than 300 nests. In three out of four years of this study, the George Lake colony was ranked as nationally significant (it was regionally significant in 2003). This lake provides ideal nesting habitat for eared grebes because it is relatively shallow, submergent vegetation is highly abundant and readily available for nest construction, there is minimal human presence on and around the lake, a powerboat restriction is in place, and the shorelines are relatively intact. The new colony found on Majeau Lake in 2004 is nationally significant. The population at Oldman Lake has plummeted $90 \%$ since 2003, possibly due to the considerable drop in water level (Hanus et al. 2003), although survey effort has also declined.

It appears that eared grebe colonies, while fluctuating in population size, are likely more stable than western grebe colonies, and have more options for nesting locations. However, continued monitoring is recommended to understand population trends and identify important breeding habitat, recognizing that eared grebes rely on a network of waterbodies and are sensitive to human disturbance.

\subsection{Western Grebe Populations in the Parkland Area}

Initial observations showed that a number of lakes in the region support western grebes, although no colonies have been located. Because surveys were reconnaissance in nature and many lakes were surveyed after the primary breeding season, evidence of breeding could easily have been missed. Lakes with poor nesting habitat may have supported transient or non-breeding populations. Several lakes appeared to have suitable nesting habitat for western grebes, so future research should focus on locating nesting colonies earlier in the breeding season.

\subsection{Management Concerns and Human Impacts on Grebe Colonies}

A variety of recreation activities and associated development have the potential to negatively impact colonial water birds. This applies in particular to grebes because they build primitive floating nests made of aquatic vegetation, which are susceptible to wave action. Recreation activities can lead to both direct (destroying nesting habitat and nests) and indirect (disturbing nesting birds) impacts on colonies, and are discussed below.

Western grebes begin the nesting process in spring using dead standing emergent bulrush habitat. During the winter, snowmobiles that drive across bulrush patches flatten reeds, so that when spring arrives, these plants lay on the surface of the water or are submerged, rendering them useless for hiding cover and protection from waves. This was evident on Isle Lake following the winter of 2001/02, causing the western grebes to build nests at an adjacent island where reeds were available, but the location was poor due to wind exposure and competition from other colonial nesting birds (Hanus et al. 2002b). During spring and summer, waves from motorboats can destroy essential reed habitat used for nesting and can potentially submerge nests.

Although destruction of nesting habitat is the primary impact of recreational activities, these activities can also create disturbances that result in grebes temporarily abandoning nests. When birds leave their nests, a number of deleterious things can occur, particularly when they leave hastily and dislodge eggs into the water or do not cover eggs with vegetation. This increases vulnerability of eggs to avian predators, and exposes eggs to extreme temperatures. In addition, new hatchlings still in the nest, and unable to survive on their own, may become permanently separated from their parents. 
The increase in recreational properties on lakes impacts western grebe populations through removal of shoreline vegetation for beach development. For example, at Wabamun Lake there is a distinct line separating the area in front of cabins where vegetation has been cleared, from the area where there is no development and the vegetation remains intact (the location of the western grebe colony). The increasing demand for recreational property will continue to threaten western grebe colonies unless appropriate legislation is put in place to protect vital nesting habitat. Caution must also be used to protect shoreline habitat from activities that disturb nesting grebes (e.g., dogs, people wading into reed beds).

The number of boats, size of motors, and types of water sport activities has increased dramatically within a relatively short timeframe, with no indication of a reverse trend in the future. Western and eared grebes require secluded areas for nesting, and if viable populations are to remain on lakes with a high presence of boaters, some boating restrictions need to be established. This is especially critical for western grebes, since they tend to colonize large lakes where boating activity is often significant. A buffer of $250 \mathrm{~m}$ to $500 \mathrm{~m}$ (depending on the size of the lake) that excludes all boating activity during the nesting period, including personal watercraft and canoes, would likely be effective. Existing motorized boating restrictions on lakes, such as George Lake, should remain in place.

Nest predation is one of the most significant threats, which can be exacerbated by human activity and settlement. The Wabamun Lake western grebe colony appears to be suffering from high rates of nest predation by corvids, the presence of which may be increasing. Similarly, predation by ringed-billed gulls at the eared grebe colonies on George Lake and Majeau Lake has been observed. In these instances, predation increased as a result of researchers being in close proximity to colonies, causing grebes to leave their nests. Throughout the course of this study, steps have been taken to minimize disturbance by not entering colonies during breeding season and restricting the time spent close to colonies (refer to Management Implications and Future Direction). Clearly, recreational boaters (including canoes) in close proximity to colonies will disturb nesting grebes. As the frequency of disturbance increases, the number of predators increases.

The sensitivity of western grebes to human disturbance has been well established, and it appears that eared grebes are also sensitive to disturbance. Five of the nine water bodies with populations and/or colonies of eared grebes are not highly developed recreation lakes and have either powerboat restrictions or are unsuitable for powerboats. It appears that eared grebes may prefer secluded and shallow lakes (e.g., Chip, George, Majeau and Oldman lakes) especially when nesting in open water areas, which is consistent with Boe (1992), who found that eared grebes preferred wetlands without designated public access, little or no fishing or motor boating, shorelines that were partially treed, and abundant submergent vegetation. Boe (1992) did not observe eared grebes on wetlands with buildings along the shoreline, suggesting avoidance behaviour.

Finally, fishing also has repercussions on water birds. In addition to the boating activity associated with fishing, abandoned fishing line poses a serious threat to water birds because diving birds can easily get snared in the relatively invisible line. During our surveys we have found a number of water birds (grebes, gulls and loons) tangled in fishing line and unable to fly, including two individuals in one eared grebe colony and a loon that lost its foot due to entanglement. The number of entangled birds we have found in this study is likely indicative of a widespread, serious problem. Obviously, it is important that anglers are aware of the dangers of improper fishing line disposal and should not discard waste line in the water. 
The Stony Plain study area supports sizable populations of both western and eared grebes, due in part to the large number of medium to large fish-bearing waterbodies. It is likely that the Parkland region also supports breeding colonies. Short-term results of this monitoring project indicate that western grebes have a high fidelity to existing nesting sites. Western grebes rely on the largest lakes in the study area to support their regional populations, where they need shoreline vegetation for nesting. Consequently, nesting sites are very limited. These lakes are also some of the most developed and well-used lakes within the study area. Public education should continue to focus on local groups, landowners, and land managers at these lakes. Shoreline habitat protection and restoration should also become a priority for this project in the future. Concern for western grebe status over the long-term continues to exist, due to the decreased nesting success of the Wabamun Lake and Lac St. Anne colonies, and encroachment by human disturbance and removal of remaining shoreline habitat.

Continued monitoring is recommended, with emphasis on post-breeding nest surveys for all western grebe colonies to estimate adult breeding population size. Further investigation is needed to locate and monitor colonies in the Parkland area to determine the population size and possibly reproductive success. Additional lakes should be included in future studies to determine the number of lakes used by western grebes to ultimately evaluate their provincial status. Determining reproductive parameters, such as clutch size, can provide valuable measures of reproductive success, but should only be calculated on an intermittent basis, such as a minimum interval of five years, to minimize disturbance. Western grebe nests should only be counted after hatching has occurred (around the $15^{\text {th }}$ of July in central Alberta), but before nests deteriorate and become unrecognizable. Because eared grebe nests are more fragile and ephemeral, an accurate count can only be made before nest abandonment. However, because they nest in open water, their eggs are highly vulnerable to avian predators. Consequently, detailed nest counts should be conducted quickly, towards the end of nesting season, and at a minimum interval of five years. In the interim, approximate nest counts can be made annually using a telescope and binoculars from an adequate distance to minimize disturbance. We recommend monitoring the largest eared grebe colonies in the area using approximate counts to assess population trends, and when possible, survey smaller breeding colonies. 


\subsection{LITERATURE CITED}

Alberta Environmental Protection. 1994. Natural Regions of Alberta: Summary. Alberta Environmental Protection. Edmonton, AB. 18 pp.

Alberta Sustainable Resource Development. 2000. The general status of Alberta wild species, 2000. Alberta Environment/Alberta Sustainable Resource Development. Edmonton, AB. 46 pp.

Boe, J. S. 1992. Wetland selection by eared grebes, Podiceps nigricollis, in Minnesota. Canadian FieldNaturalist 106:480-488.

Cullen, S. A., J. R. Jehl, Jr., and G. L. Nuechterlein. 1999. Eared Grebes (Podiceps nigricollis). The Birds of North America 433: 1-27.

Hanus, S. 2003. Waterbird survey compilation for the Stony Plain Area, 2001 to 2003. Alberta Sustainable Resource Development, Fish and Wildlife Division. Hinton, Alberta.

Hanus, S., L. Wilkinson, and H. Wollis. 2002a. Western (Aechmophorus occidentalis) and Eared (Podiceps nigricollis) Grebes of Central Alberta: 2002 Field Summary. Alberta Sustainable Resource Development, Fish and Wildlife Division, Alberta Species at Risk Report No. 60. Edmonton, AB. http://www3.gov.ab.ca/srd/fw/riskspecies/

Hanus, S., H. Wollis, and L. Wilkinson. 2002b. Western (Aechmophorus occidentalis) and Eared (Podiceps nigricollis) Grebes of Central Alberta: Inventory, Survey Techniques, and Management Concerns. Alberta Sustainable Resource Development, Fish and Wildlife Division, Species at Risk Report No. 41. Edmonton, AB. 45pp. http://www3.gov.ab.ca/srd/fw/riskspecies/

Hanus, S., L. Wilkinson, and H. Wollis. 2003. Western (Aechmophorus occidentalis) and Eared (Podiceps nigricollis) Grebes of Central Alberta: 2003 Field Summary. Alberta Sustainable Resource Development, Fish and Wildlife Division. Edmonton, Alberta.

Jehl, J. R. Jr., W. S. Boyd, D. S. Paul, and D. W. Anderson. 2002. Massive collapse and rapid rebound: population dynamics of eared grebes (Podiceps nigricollis) during an ENSO event. The Auk 119 (4): $1162-1166$.

Poston, B., D. M. Ealey, P. S. Taylor, and G. B. McKeating. 1990. Priority migratory bird habitats of Canada's prairie provinces. Minister of Supply and Services Canada. Edmonton, AB. 107 pp.

Purdy, R.O., D.C. Parkyn, and J.D. Folinsbee. 1983. Wildlife surveys of selected Edmonton area lakes June-July 1982. Unpub. Rep. Alberta Energy and Natural Resources, Fish and Wildlife Division. $139 \mathrm{pp}$. 


\subsection{APPENDICES}


Appendix 1. Map of Study Areas in Alberta

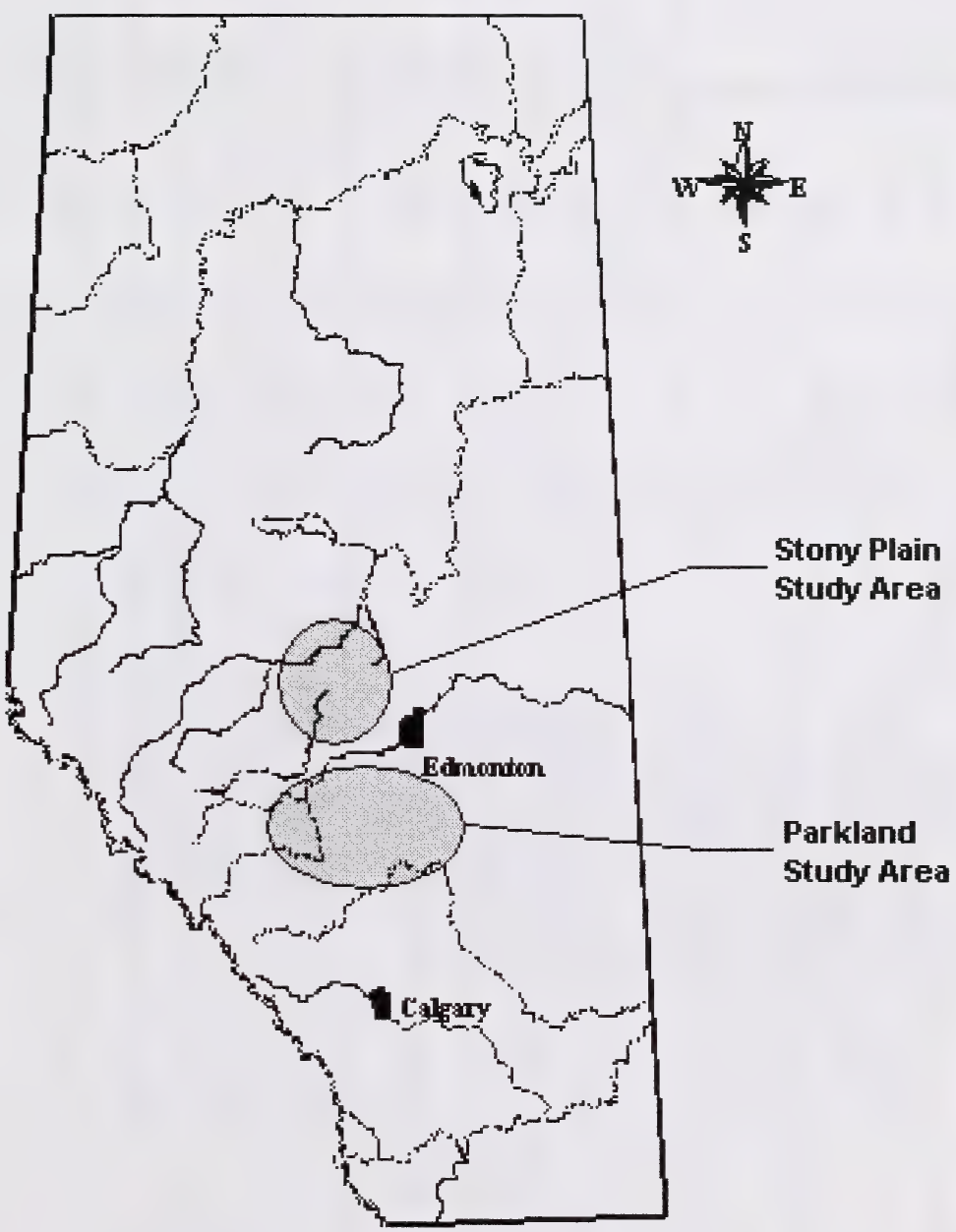




\begin{tabular}{|c|c|c|c|c|c|c|c|c|c|c|}
\hline 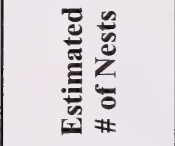 & $\underset{Z}{\mathbb{Z}}$ & $\vec{\sim}$ & $\underset{\sim}{\stackrel{\Xi}{\sim}}$ & t) & $\underset{z}{\longleftarrow}$ & さ્તે & $\frac{\nwarrow}{z}$ & $\frac{\varangle}{z}$ & $=$ & $\underset{\mathrm{z}}{\nwarrow}$ \\
\hline 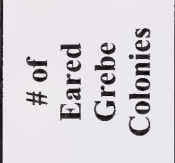 & $\mid \begin{array}{ll}0 & \\
z & 0 \\
\lambda & 0 \\
0 & 0 \\
0 & 0 \\
0 & 0\end{array}$ & $\sim$ & $\sim$ & - & 0 & $\nabla$ & 0 & 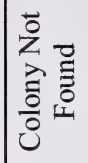 & - & 0 \\
\hline 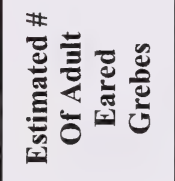 & $N$ & 으 & $\begin{array}{l}\infty \\
\stackrel{\infty}{+}\end{array}$ & t) & 0 & $\begin{array}{l}\infty \\
\infty \\
\stackrel{n}{\gamma}\end{array}$ & 0 & $r$ & ป & 0 \\
\hline 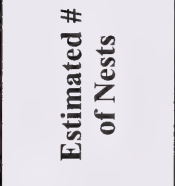 & $\frac{\nwarrow}{z}$ & $\underset{z}{\nwarrow}$ & $\overleftrightarrow{\mathrm{z}}$ & $\frac{\nwarrow}{z}$ & $\frac{\nwarrow}{z}$ & $\frac{\nwarrow}{z}$ & $\frac{\nwarrow}{\mathrm{z}}$ & $\simeq$ & ร & $\simeq$ \\
\hline 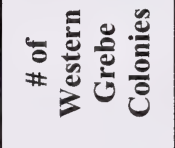 & 0 & 0 & 0 & 0 & 0 & 0 & 0 & $N$ & $N$ & - \\
\hline 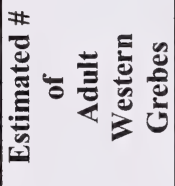 & 0 & 0 & 0 & 0 & 0 & 0 & 0 & $\tilde{n}$ & $\stackrel{\infty}{\varrho}$ & ్ల \\
\hline 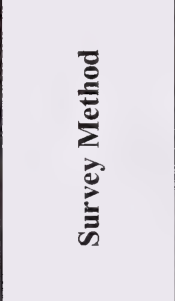 & 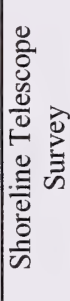 & 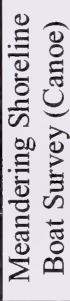 & 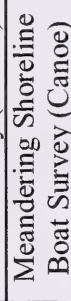 & 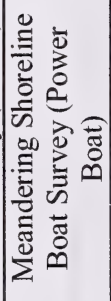 & 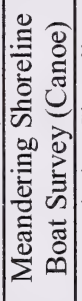 & 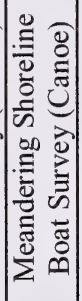 & 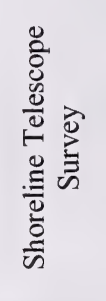 & 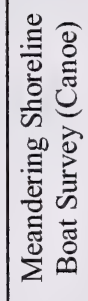 & 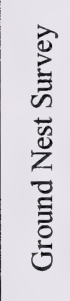 & 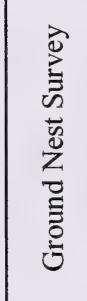 \\
\hline 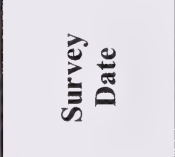 & $\begin{array}{l}\text { ป̂. } \\
\stackrel{0}{0} \\
\Xi\end{array}$ & $\stackrel{N}{\Xi}$ & $\begin{array}{l}\stackrel{\hat{~}}{0} \\
\vdots \\
\Xi\end{array}$ & $\mid \begin{array}{l}0 \\
0 \\
0 \\
2 \\
\vdots \\
\vdots \\
\vdots\end{array}$ & $\mid \begin{array}{l}0 \\
0 \\
0 \\
2 \\
\Xi \\
\Xi\end{array}$ & $\begin{array}{l}\tilde{\sim} \\
\stackrel{0}{0} \\
\Xi\end{array}$ & 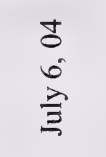 & 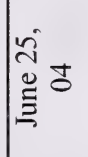 & $\begin{array}{l} \pm \\
n \\
\frac{2}{\Xi}\end{array}$ & 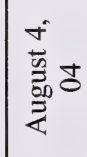 \\
\hline 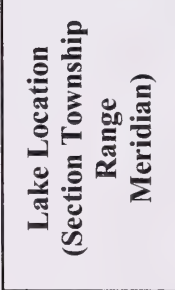 & $\begin{array}{l}n \\
3 \\
n \\
n \\
\tilde{n} \\
\tilde{\omega} \\
\tilde{a} \\
\tilde{\omega}\end{array}$ & 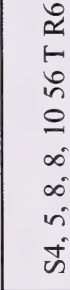 & 3 & 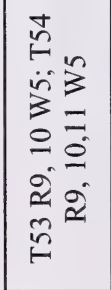 & $\begin{array}{l}n \\
3 \\
2 \\
2 \\
3 \\
6 \\
0 \\
\tilde{0} \\
\tilde{n}\end{array}$ & 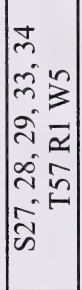 & 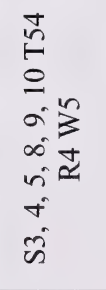 & $\begin{array}{l}\ddot{n} \\
3 \\
2 \\
\tilde{n} \\
\tilde{n} \\
\frac{1}{\pi} \\
\frac{1}{n}\end{array}$ & 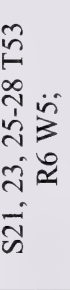 & 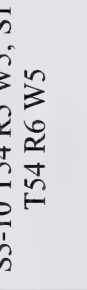 \\
\hline 冚 & 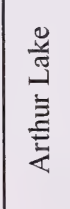 & 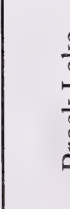 & 范 & 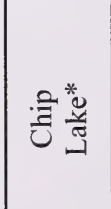 & 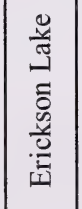 & 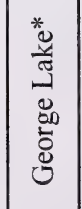 & $\begin{array}{l}\text { 苞 } \\
\text { 离 } \\
0 \\
0 \\
0 \\
0 \\
0\end{array}$ & & 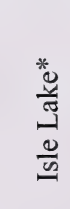 & \\
\hline
\end{tabular}




\begin{tabular}{|c|c|c|c|c|c|c|c|c|c|c|}
\hline 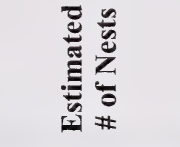 & $m$ & $\frac{\nwarrow}{z}$ & $\frac{\nwarrow}{乙}$ & $\underset{\mathrm{z}}{\longleftarrow}$ & $\hat{a}$ & $\nabla$ & $\underset{\mathrm{z}}{\longleftarrow}$ & $\underset{Z}{\varangle}$ & 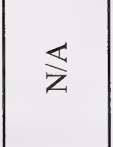 & $\underset{z}{\ll}$ \\
\hline 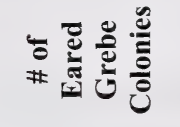 & - & 0 & 0 & 0 & $N$ & - & 0 & 0 & 0 & $\underset{z}{\varangle}$ \\
\hline 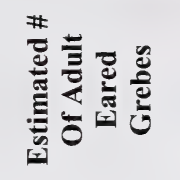 & 0 & 0 & 0 & 0 & $\begin{array}{l}\text { ¿े } \\
\text { ஸे }\end{array}$ & $\stackrel{\infty}{\sim}$ & 0 & $\begin{array}{l}t \\
0\end{array}$ & 0 & $\underset{z}{\nwarrow}$ \\
\hline 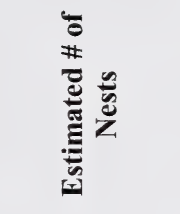 & $\stackrel{ \pm}{n}$ & $\underset{\mathrm{z}}{\ll}$ & $\frac{\nwarrow}{Z}$ & $\underset{\mathrm{z}}{\varangle}$ & $\underset{z}{\varangle}$ & $\frac{\nwarrow}{z}$ & $\frac{\nwarrow}{\mathrm{Z}}$ & $\underset{z}{\nwarrow}$ & $\frac{\nwarrow}{z}$ & $\frac{N}{m}$ \\
\hline 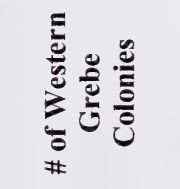 & $\sim$ & 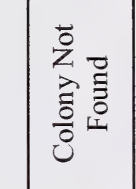 & 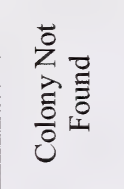 & 0 & 0 & 0 & 0 & 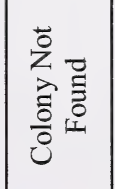 & 0 & - \\
\hline 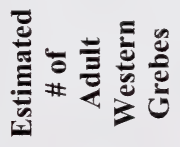 & $\stackrel{\infty}{\stackrel{\infty}{0}}$ & $\stackrel{t}{\circ}$ & $\bar{\gamma}$ & 0 & 0 & 0 & 0 & $a$ & 0 & సु \\
\hline 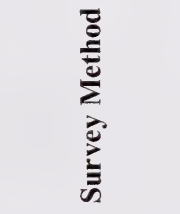 & 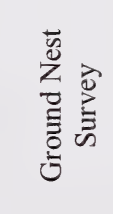 & 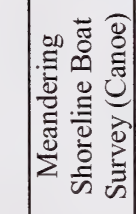 & 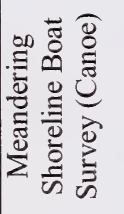 & 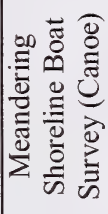 & 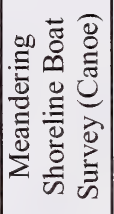 & 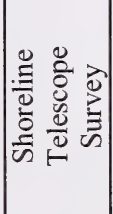 & 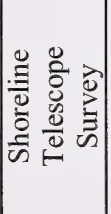 & 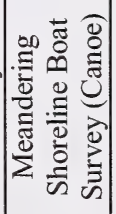 & 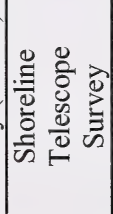 & 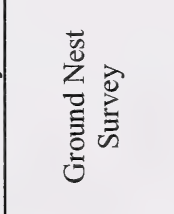 \\
\hline 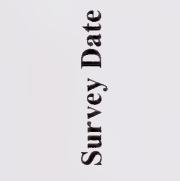 & $\begin{array}{l} \pm \\
\vdots \\
\pm \\
\vdots\end{array}$ & 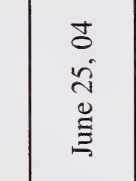 & 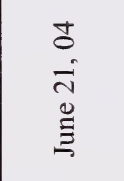 & 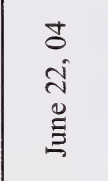 & 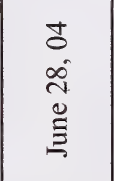 & $\begin{array}{l}\Xi \\
\tilde{ป} \\
\Xi \\
\Xi\end{array}$ & $\begin{array}{l}\text { ठ } \\
\text { సे } \\
\Xi \\
\Xi\end{array}$ & $\begin{array}{l} \pm \\
n \\
2 \\
\Xi\end{array}$ & $\begin{array}{l} \pm \\
0 \\
0 \\
\grave{\Xi}\end{array}$ & $\begin{array}{l}J \\
\frac{1}{2} \\
\frac{2}{\Xi}\end{array}$ \\
\hline 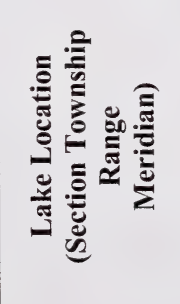 & & 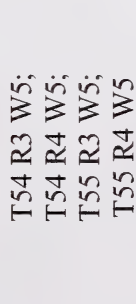 & & 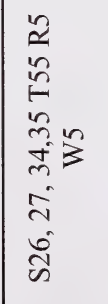 & 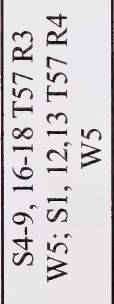 & 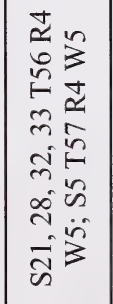 & 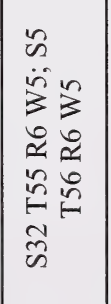 & $\begin{array}{l}n \\
\frac{n}{a} \\
n \\
n\end{array}$ & 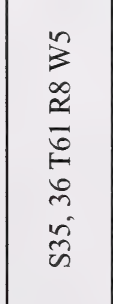 & 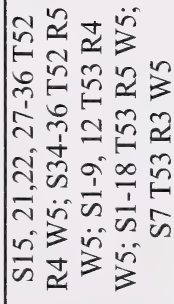 \\
\hline 竎 & 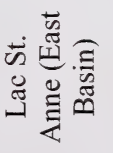 & 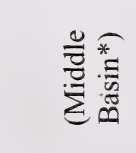 & 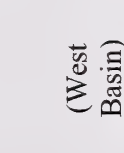 & 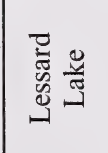 & 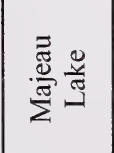 & 壱 & 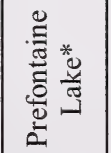 & 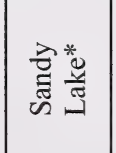 & 总 & 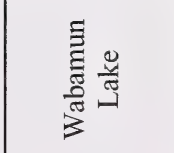 \\
\hline
\end{tabular}


Appendix 3. Western grebe nest quality during post breeding season total nest counts

\begin{tabular}{|l|c|c|c|c|c|}
\hline \multicolumn{1}{|c|}{ Lake } & Date & $\begin{array}{c}\text { Total \# of } \\
\text { Nests }\end{array}$ & $\begin{array}{c}\text { \# of Intact } \\
\text { Nests }\end{array}$ & $\begin{array}{c}\text { \# of Partially } \\
\text { Submerged Nests }\end{array}$ & $\begin{array}{c}\text { \# of Submerged } \\
\text { Nests }\end{array}$ \\
\hline Isle Lake & July 15, 2004 & 99 & 25 & 59 & 15 \\
\hline Isle Lake & Aug. 4, 2004 & 15 & 0 & 7 & 8 \\
\hline Lac Ste Anne & July 14, 2004 & 154 & 28 & 76 & 50 \\
\hline Wabamun & July 15, 2004 & 317 & 0 & 45 & 272 \\
\hline
\end{tabular}




\section{Species at Risk Report Series}

For a complete list of titles in the Species at Risk report series, visit the following website, an select 'Project Reports':

http://www3.gov.ab.ca/srd/fw/speciesatrisk/index.html 
NATIONAL LIBRARY OF CANADA

Bibliothèque nationale du Canada

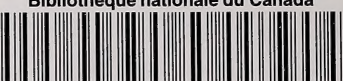

33286530314653 